\title{
Factors that Hinder Effective Conflict Management in Ghana: Evidence from Asante Akyem North District
}

\author{
Seth Peter Frimpong ${ }^{1}$, Anthony Bordoh ${ }^{1^{*}}{ }^{\complement}$, Isaac Eshun $^{1}{ }^{\circledR}$, Anderson Oppong Twumasi $^{2}$, Emmanuel \\ Nomah $^{3}$, Frank Ato Tabil ${ }^{4}$ \\ ${ }^{1}$ Department of Social Studies Education, University of Education, Winneba, Ghana \\ ${ }^{2}$ Department of Basic Education, University of Education, Winneba, Ghana \\ ${ }^{3}$ Department of Social Sciences, Dambai College of Education, Dambai, Ghana \\ ${ }^{4}$ Department of Social Sciences, Seventh Day Adventist College of Education, Asokore-Koforidua, Ghana \\ Email: bordohlity@yahoo.co.uk
}

Received: 21 February 2021; Revised: 27 July 2021; Accepted: 27 July 2021

\begin{abstract}
The purpose of the study was to examine the factors that hinder effective conflict management in Asante Akyem North District in the Ashanti Region of Ghana. The Population of the study included leaders of the various conflict management groups/individuals who have been involved in forestalling peace in Agogo in Asante Akyem North District in the Ashanti Region of Ghana. The case study design was adopted for the study. A purposive sampling technique was used to select all the twelve (12) participants for this study. The main instrument used for data collection for the study was an interview guide. The study revealed that the conflict between the farmers and the nomads in the Agogo could only be dealt with if there is no political power backing Fulani herdsmen in the enclave of Agogo. The study also concluded that the Fulanis have been able to defy the orders of the court by not withdrawing from the Agogo area. It is also recommended that the Government of Ghana and traditional authorities in Agogo State should be firm and fair in the management and implementation of court decisions with regard to the farmer-nomad conflict of Agogo. The politicisation of farmer and nomad conflicts, in particular, is thwarting efforts at forging cooperation and resolution of the conflict.
\end{abstract}

Keywords: farmer-nomad conflicts, Asante Akyem North, Ghana

\section{Introduction}

Conflicts between farmers and nomads have been a major social challenge that has bedeviled the world. They are highly pronounced in developing countries, especially in Africa, as Africa seems to be a continent where there seems to be conflict year in, year out (Soeters et al., 2017). Farmer-herder conflict happens to be one of such conflicts, as in the riparian states that share the Lake Chad (Chad, Niger, Cameroun and Nigeria) in West and Central Africa are still grappling with farmer-pastoralist conflict over claims and ownership of land and forest resources arising from an increase in the number of users, receding lake water and desertification that heated the region since 1980s (Jumba, 2011). Also, in South-West Burkina Faso, the conflict between Fulani pastoralists and Dagora, Birifor and Lobi farmers has been a recurring decimal (Tonah, 2002). Ethiopia is also grappling with farmer-herder conflict in Quowet Wareda of Amhara region resulting from increasing pressure on land (Daniel, 2003).

Copyright (C2021 Anthony Bordoh, et al.

DOI: https://doi.org/10.37256/ser.222021795

This is an open-access article distributed under a CC BY license

(Creative Commons Attribution 4.0 International License)

https://creativecommons.org/licenses/by/4.0/ 
Berry (2002) stated that competition over land in Africa is not new, but it has become pervasive, associated with deepening social differentiation among land users, and has increasing significance in national and international affairs as well as in localized arenas. Roughly, a third of the nomads continue to follow a traditional semi-nomadic, cattlerearing lifestyle that increasingly brings them into conflict with settled agriculturalists at a time of increased pressure on resources such as pastureland and water. This has become a contemporary issue in Ghana as the conflicts keep recurring in the country. Wehrman (2008) posited that the most violent conflicts over land are those that involve two groups, often two different ethnic groups, fighting over their property.

Studies across the continent document the widespread contestation around land within and between regional and ethnic groups, within and between descent groups or lineages, and between generations and genders as land has become more valuable, more difficult to attain and keep (Boone \& Duku, 2012; Colin \& Ayouz, 2006). Current conclusions from research are that competition and conflict over land and over the authority to control, use, allocate, and transfer lands are pervasive; they occur between groups differentiated on the basis of origin, region, and ethnicity; they divide kin-based groups (lineage, descent group) and resident groups (villages, wards); and they set generations and genders against each other.

The conflicts are a threat to peace and national stability. It also has implications for tribal co-existence as Ghana is a multiethnic nation. Indeed, nation-building shall continue to suffer from strong divisive forces of ethnicity, religion and natural resources conflict, and this reveals the weakening of national cohesion and integration (Maiangwa \& Ahmadu, 2007). The development of farmers and nomads' conflicts, and in particular, the treatment of nomads by host communities and vice versa has got not only national implications, but also implications for the relations between people from Agogo and the Fulani communities in Ghana. This reflects Jumba's (2011) assertion that "farmer-pastoralist conflicts are mostly envisaged as ethnic and easily articulated into ethnic or indigene-settler conflict" (p. 8).

The numerous studies that have been conducted on the causes, effects and measures to solve the conflict in Agogo such as Bukari and Schareika (2015), Olaniyan et al. (2015), and Opoku (2014) did not give due recognition to the previous attempts at solving the conflict that have failed. Again, evidence of systematic research on the prevailing dynamics of nomads and farmers' conflict, and on the methods of managing it in the Asante Akyem (Agogo) area is quite scanty despite its obvious consequences. This does not, however, suggest that scholars have not engaged in the general description of the methods of managing nomads and farmers' conflict in the area (Albert, 1999).

\section{Review of the literature}

The character of the local or traditional system affects the expectations of traditional or local institutions and the strategies they may use to break out of a conflict (Miller, 2005). Features such as polarity of the traditional system, patterns of alignments, and distribution of power capabilities are all associated with different approaches to conflict (Gochman, 1993). A bipolar traditional or local environment, for instance, is likely to be more stable than a multipolar system in encouraging a balance between caution and resolve in responding to conflicts (Waltz, 1979). The termination of intractable conflicts can be explicitly linked to the nature of the traditional environment in which they occur (Miluwi, 2015).

The nature of a conflict or the characteristics of the issues that are its focus is clearly crucial in determining how it is managed (Diehl, 1992). Certain issues such as beliefs, core values and territorial integrity have a high saliency and are apt to encourage decision-makers to accept higher levels of costs. This makes it much more difficult to manage such conflicts through traditional diplomatic methods (Snyder \& Diesing, 2015). Conflicts over salient issues are likely to be long-lasting and to entail the use of coercive methods as a way of reaching an outcome. Other aspects such as the number of issues in conflict, the rigidity with which they are perceived, whether they relate to tangible interests (for example, resource conflict) or intangible ones (for example, conflict over values) may also affect both the duration and the method of termination (Toku, 2014).

The third contextual dimension that affects conflict management is that of the internal characteristics of the actors involved. This refers to how certain structural properties of local or traditional institutions and states affect their predisposition to engage in coercive or other forms of conflict management. The nature of the polity has attracted the most attention recently (Gelpi, 2017; Hudson et al., 2019). Here the argument is that democratic individuals and states are more inclined to use peaceful methods of conflict management (because of internal norms, liberal experience) 
whereas non-democratic individuals are more likely to utilize coercive methods of management.

Another factor relates to the power capabilities of individuals, traditional institutions and states. Although there is not much empirical evidence to suggest a strong relationship, power capabilities can be linked to different conflict management behaviours (for example, a conflict between two equally strong parties or people may be prolonged because both have the material and human resources to carry on, and the willingness to tolerate high costs). All these contextual factors affect directly the disposition to engage in different forms of conflict management, and how a conflict will terminate.

The effects of some contextual factors on the origin, character and evolution of a conflict have been documented quite extensively (Stoll, 1993). Some studies have examined more specifically their effect on conflict management. A number of propositions linking, for instance, the duration, intensity, fatalities and issue prominence to effective mediations (Miluwi, 2015) received considerable theoretical and empirical support. Other studies linked the parties' internal characteristics (Young et al., 2018) or power capabilities between them (Miluwi, 2015) to different forms of conflict management by third parties. Managing conflicts is a broad skill to acquire. However, several other factors have been identified as affecting the effectiveness of conflict management. Among such factors are:

\subsection{Deadly weapons}

An earlier attempt in 2004 to evict the herdsmen proved futile as the Fulani's were heavily armed with AK-47 rifles. This even made the residents detest the Fulani's (Adzahile-Mensah et al., 2016). The Fulani's are accused of raping women at gunpoint in their farms (Ibrahim, 2014). According to the farmers and district officials, there have been reported cases of shootouts, deaths and rape caused by the herdsmen (Dosu, 2011). The herdsmen and cattle owners, on the other hand, claimed to have lost some of their animals through physical attacks and poisoning by the use of agrochemicals by the farmers (Adzahile-Mensah et al., 2016). Even though the Dadson Committee found in the possession of Fulani herdsmen sharp knives and cutlasses, they could not establish the use of sophisticated weapons, such as AK-47 assault rifles as was alleged by the inhabitants of the Agogo community during the period of its investigations (Ibrahim, 2014).

\subsection{Disregard to the rule of law}

The District Assembly is the political and administrative representative of the national government at the local level. The Kumasi High Court on January 20, 2012, ruled that Fulani herdsmen should be evicted from the area, but the state failed to execute the orders of the court (Graphiconline, 2016). Speaking to Citi News on August 12, 2016, spokesperson for the residents, Kingsley Obeng, said the activities of Fulani herdsmen have not ceased, adding that the herdsmen are still preventing residents from visiting their farms. Speaking to Citi News on a report by Mary Ansah in 2016, spokesperson for the residents of Agogo, said the activities of Fulani herdsmen have not ceased, adding that the herdsmen are still preventing residents from visiting their farms since they do not respect the laws of the land.

\subsection{Politicization of farmer-nomads conflict}

Cattle owners and Fulani herdsmen attributed the perennial conflicts to political manipulations. A cattle owner in Agogo claimed that the conflict between Fulani herdsmen and farmers in the area is political. Ibrahim (2014) stressed that the strained relationship between the government and the traditional authorities makes it difficult to effectively cooperate and co-ordinate to nip the perennial conflicts between farmers and Fulani in the bud. In his view, the situation is beset with political rivalry in both mainline and traditional politics that makes it difficult to deal with the situation decisively (Ibrahim, 2014).

\subsection{Communication barrier}

Communication is the process of sharing and exchanging information between individuals, groups and potential parties in a conflict resolution. Communication relates to the presence and sharing of accurate information about a conflict situation, being able to talk about feelings and concerns of parties, speaking about what parties would like to 
change, and discussing the nature and type of conflict, touching on the positions, interest, needs and fears of parties. Poor communication or the absence of communication about these and other subjects, or a misinterpretation of the needs and feelings of one another by conflict parties, can easily lead to the escalation of the conflict (Obeng, 2015). Communication was essential in the Cuban Missile Crisis in 1962. The Cuban Missile Crisis was a major confrontation during the Cold War between the United States and the former Union of Soviet Socialist Republics (USSR) over the issue of Soviet-supplied missile installations in Cuba. To solve this conflict, the two nuclear powers decided to keep communication channels open, clarify intermediaries (Schelling, 1960). It brought to the fore, the fact that the absence of information over the intentions, movements and plans of both countries created deep anxiety capable of creating a major explosion (Obeng, 2015).

Even though the Cuban Missile Crisis did not invent the use of communication in conflict and crisis management; it helped to popularize it at the international level. Communication has come to represent a key strategy of conflict management, such as collaboration, negotiation and dialogue; as well as third-party interventions like mediation, conciliation, arbitration and adjudication which are largely dependent on effective communication (Obeng, 2015).

What third-party interveners do is to bring about an enhanced process of "controlled communication" (Burton, 1990) between parties in any given conflict (Obeng, 2015). This keeps the parties seeing each other, interacting with each other and talking to each other about their problem, intending to generate workable solutions to the issues in the conflict. Once communication is lost, parties risk getting into a deeper crises that cannot be easily resolved. Thus communication is invaluable for conflict prevention in the first instance, and then for conflict resolution (Obeng, 2015).

The communication barrier was also another contributing factor to the conflict management between farmers and nomads in the Agogo traditional area. The majority of Fulani herdsmen who are mostly from Nigeria, Burkina Faso, Niger and Mali do not speak the Twi language which is predominantly spoken in the Asante Akyem area. They can hardly speak English or the pidgin language properly. This makes it difficult for smooth interactions between the two groups. The farmers accuse the herdsmen of feigning ignorance of the Twi language even though they can comprehend what is been communicated to them.

\subsection{Cattle rustling and killing}

Cattle owners and Fulani herdsmen contend that cattle rustling contributes in no small measure to the conflicts in the Agogo traditional area. The animals are rustled when they go to graze. According to one cattle owner, the cattle are killed in the forest and the meat is transported to the town market to sell. In addition, cattle owners claim dissatisfied farmers shoot cattle that stray into their farms on sight. Recalling an incident indicated that about seven cattle went to drink water by the riverside and when the animals strayed into someone's farm, the owner shot the animals on sight even after negotiations have been made for him to pay the necessary compensation.

\section{Materials and methods}

The case study design was adopted for the study. According to Creswell (2013), "The case study method "explores a real-life, contemporary bounded system (a case) or multiple bounded systems (cases) over time, through detailed, in-depth data collection involving multiple sources of information... and reports a case description and case themes" (p. 97). Seidu (2012) is of the view that "case study involves an intensive investigation on the complex factors that contribute to the individuality of a social unit-a person, family, group, social-institution or community" (p. 56). He emphasizes that the purpose of a case study is to understand the life cycle or an important part of the life cycle of the unit through the study of an aspect or a part. He further posits that the greatest strength of the case study method is that it allows the researcher to concentrate on a specific instance or situation and to identify the various interactive processes at work, and such processes may remain hidden in a large scale survey but may be crucial to the success or failure of the system or organization. The researchers employed the qualitative approach because the nature of the study generated knowledge by examining farmers and nomads' conflict management at the Asante Akyem North District in the Ashanti Region of Ghana. The Population of the study includes leaders of the various conflict management groups/individuals who have been involved in forestalling peace in Agogo: the District Chief Executive (DCE) of the Asante Akyem North District, District Police Commander (DPC) of Asante Akyem North District, a leading elders of the community, 
Spokesperson for the nomads, a leading member of the cattle owners, Registrar of the Agogo Traditional Council, leading member of the farmers' association, youth leaders from the affected communities and assembly member and an agricultural extension officer. A purposive sampling technique was used to select all the twelve (12) participants for this study. It included the DCE, DPC, two leading elders of the community, leader of the farmers' association group, two youth leaders of the affected communities, one assemblyman, the Registrar of Agogo Traditional Council, the spokesperson of the nomads, one leading member of the cattle owners' association of Agogo and one agricultural extension officer. For the purpose of this study, there were two major sources of data available to help the researcher to complete the study. The study employed both primary and secondary sources of data. In the case of primary sources, the researcher collected 'fresh' data from participants who are termed as the sources of primary data in the work. It was useful to employ the primary source of data such as the interview guides to gather data on the objectives of the research. The primary sources were the original responses and reports which were solicited from the participants. Secondary sources of data, on the other hand, constituted different written documents. For instance, press releases, newspaper publications, articles, court rulings and other related documents linked to the farmers and nomads' conflict in Agogo. The interview guide was the main instrument used for the study. Data collection was done through the administration of interviews. The participants were interviewed individually using a interview guide. And analyses were done by the use of descriptive and interpretive techniques based on the themes arrived at in the data collection.

\section{Results}

This section of the study presents findings and discussions on the research question-What are the factors affecting the effectiveness of the conflict management methods in the Asante Akyem North District? The research question aimed to ascertain the failure of the conflict management methods adopted to control the farmer-herder conflict in Agogo. Identifying the factors that affect the effectiveness of conflict management is vital in bringing an end to this thorny issue in Agogo. Participants were asked series of questions on what they think constitutes the major factors that have affected the effectiveness of the conflict management methods between the farmers and nomads in Agogo. Many conflict management methods have been employed to curb this menace but to no avail. This question was therefore asked to bring to light the hindrances to the effectiveness of the conflict management methods adopted to curb the conflict between farmers and nomads in Agogo, as clarified in the discussions that follow. The study identified the following as the reasons why these management methods have not succeeded: ineffective policing, the use of deadly weapons, interference, politicisation and personal interest, bribery and corruption and greediness.

\subsection{Ineffective policing}

It was revealed from the responses by the interviewees that policing in the Agogo area has not been very effective and has occasioned the continual failure to curb the conflict between the farmers and the nomads in the Agogo area. The responses below give reasons for the failure of the conflict management methods adopted to control the farmer-herder conflict in the Agogo area.

The Police commander asserted that:

"The Police only go on patrol in the afternoon and return to the station. This is because we have only one service vehicle and we cannot station it in one affected community. So, it is very difficult to deploy men to go on patrol especially in the evening. Fueling the car every day and accommodating personnel is costly. The indigenes are also not helping us. Some townspeople are traitors. Some rent their houses to the nomads and allow them to marry from their families. They keep on giving the nomads information as to when the Police are coming, where they are coming from and all that... The Fulani's leave their cattle to graze freely, especially at Kowreso. Whenever you receive information, you will get there without meeting anybody".

As noted from the responses above, the conflict between the farmers and the nomads at Agogo lingers on despite the various conflict management methods adopted to control it because policing in the area is very ineffective. This, according to the interviewee, is due to a lack of resources in policing the area, which seems to make it difficult for the 
police to frequently visit the affected communities. It should therefore be noted from this account that the state actually has not been proactive in dealing with the farmer-herder conflict in the Agogo area. The responses from the police officer show that the police have the mandate to patrol the communities but they are constrained by a lack of logistics.

Again, it became known from the interview with the police officer that there seems to be some kind of unfaithfulness on the part of both the indigenes and the police. That is, from the response of the police commander, while the people revealed their mistrust for the Police, the police also showed their lack of confidence in the indigenes clearly. The police, however, think that they are doing a yeoman's job but the people of Agogo accuse the police of aiding the nomads for whatever reason that is best known to them; the police also see the people as rather aiding the activities of the nomads by giving them information about the operations of the Police, especially when they are going to where the nomads are. This makes the nomads the ultimate beneficiaries of the issue though the nomads also accuse the police of overcharging them for their self-gain. There is therefore an apparent mistrust between the security apparatus and the community members which affects the management of the conflict in Agogo. Nonetheless, judging from the information given by both the indigenes and the nomads, something becomes clear. That is, as the farmers accuse the police of aiding the activities of the nomads for some ulterior motive, the nomads also confirm this by revealing that the police overcharge them for their selfish gain. In view of this, the fact still remains that the Fulanis have obviously become very powerful in the area, possibly due to their ability to usurp the powers of the authorities in the area and extend it to the nation, as to have the temerity to defy the orders of a competent court of jurisdiction.

From the words of the police officer interviewed, it seems that authorities have not committed many resources to deal with the conflict. This makes the security, social and political institutions and leaders fragile and incompetent. This, therefore, erodes the people's confidence in the government and generates more conflicts. The issue of lack of resources for the police was in fact conspicuously missing in the findings of Frederick et al. (2014) but he equally reported the lack of confidence the people have developed for the police. According to him, the recourse to the police or court in the Agogo area regarding the farmer-herder conflict tended to be the most hated mode of conflict resolution and most sparingly used. He further noted that the farmers saw the police as being in bed with the herders while the herders also considered the police as exploitative. The findings by Frederick et al. (2014) as well as the current study have clearly identified the reason for the escalation of the farmer-herder conflict in the Agogo area. However, this finding is contrary to Milligan's (2007) assertion that the emergence of the police and local governments, as alternative institutions for conflict management, is probably a more significant change to rural communities than the weakening customary institutions.

\subsection{The use of deadly weapons by the nomads}

Another reason why the conflict management methods adopted to control the conflict have not been successful is the use of deadly weapons by the nomads, as can be seen in the responses below.

One farmer reckoned that:

"The herdsmen are armed. You cannot organize them as a people. Expensive weapons are carried by the Fulanis, but the civilians have no weapons. The Police arrest farmers for holding guns or stones, even if it is for farming purposes. If for nothing at all, the farm is at one place, but the cattle move around. They cannot do their work at night because of poor visibility...even in day time they were attacked. The soldiers sack Fulanis whenever the natives give them an alert. But the police will arrest a farmer for having a gun...at times farmers are even searched. That is not the case for Fulanis".

One of the participants, Opayin Yaw Manu, recounted that "Fulani in the olden days used only stick even when lions and wild animals were rampant...so where are all these expensive arms (guns) from?"

The chairman of the cattle owners' association also asserted that "The Fulanis are forced to get guns because some of the farmers use weapons to kill their cattle and sell them in town. The cattle rearing too is expensive for us".

The leader of the farmers' association reiterated that:

"All this talk about the intensification of the "operation cow leg" this year is nothing new... They are only 
doing this because, two security personnel, a soldier and police were shot by Fulani when on patrol. So, these security personnel are also ready to kill. Just last week, a lady, who is a rice seller, fought a Fulani and collected the gun of a Fulani".

One Agricultural Extension Officer stated that:

"The Fulanis when they see you on the farm, can point their own gun or cutlass at you and tell you 'Abokyi' (friend) the cattle are coming to eat...if you resist or talk back to them; they can shoot you for talking. They even tie farmers and rape their wives or children before their eyes. One day while I was going for an area inspection, one person was killed just because the Fulani was annoyed... He narrates that the Fulani claimed the person (killed) identified the Fulani as one that burnt his farm".

The use of deadly and destructive weapons such as guns, cutlasses and clubs by the nomads affected the management of the conflict; and following from the earlier discussion, where the police are not well resourced to deal with the conflict, the management of this conflict becomes impossible. The question that can therefore be posed regarding the possession of these deadly weapons by the Fulanis is; where and how do they get these weapons from? The answer to this question could still be pointing to the police force, and possibly the high-ranking officials in the country that may be supporting the activities of the nomads for their selfish gains, to the detriment of the common farmer. This confirms an assertion by Adzahlie-Mensah et al. (2016), Dosu (2011) and Ibrahim (2014) that the nomads were accused of shootouts, deaths and raping women at gunpoint (Ibrahim, 2014). Regarding the Fulani's disregard of the court order, as this study has shown, a report on Graphic Online (2016) indicates that the Government of Ghana (state) failed to execute the orders of the Kumasi High Court which ruled that Fulani herdsmen should be evicted from the area.

\subsection{Interference}

Interference by some unknown powerful people at the local, regional and national level has also been one of the issues that hinder the management of the farmer-herder conflict in the Agogo area. The responses below explain this issue further.

The DCE was of the view that:

"The Fulani's have weak kraal. They see the ranching system as very expensive. They see that humans are born free and animals too are born free. But the government is ready to support them with boreholes and special grass. Regrettably, they see it as an expensive venture. Herdsmen are not ready to move to a safer place to make way for farming by the farmers".

The spokesperson for the Fulani asserted that:

"There is always this talk about Fulanis killing farmers and destroying their farms... "Masa", the farmers also equally kill some of the Fulanis and steal some of the cattle. Where do they also get the guns? One farmer named Yaw is in prison for life because he shot a Fulani. Some are not part but they have included all herdsmen. Consequently, there is a struggle... Now the cattle feed at night though they should be sleeping in the night. They are also not ready to talk. They can kill you when you ask them to lead their cattle away".

One youth leader remarked that:

"They thought they had a place for their cattle so they were unwilling to dialogue with the farmers or any group. The farmers too lamented that they have abandoned plans to consider the option of arbitration over the conflict... They were always pleading, but to no avail because of the behaviour of the nomads. The Fulani's are not the owners of the cattle. They claim the cattle were not for them. At the time, a District Chief Executive (DCE) of the area was removed from office because he was seriously fighting against the presence of the 
Fulanis. This makes our leaders lack the political will to flush out the Fulanis from Agogo".

One of the assemblymen also remarked that:

"High and powerful people in the Ghanaian society own the cattle... They are just concerned or worried that more cattle are dying, but when a Fulani dies he will bring another one. They have strong and fabulously rich men who protect them. Even when a Fulani is arrested, the following day, he will be set free. One day, a Fulani was bailed with GHC 8000. They are now bringing in religious elements. The Chief Imam and the larger group went to see the President. Why? For the government to impose it on the people or what?"

One leading member of the community revealed that:

"The cattle are not for the Fulanis. They are for big gurus in society because of their self-seeking interest. I tell you they are for people from higher places, businessmen, politicians, police and soldiers. It is making the conflict linger on. The Fulani don't have the money to rear the cattle. These people are supporting them... even buying them guns. One assemblyman even led the security personnel in one of their patrols. Some cattle owned by important personalities in the society were protected. The cattle were for chiefs, top police officers and top personalities in Ghana. They are the people whose cattle can only be protected by the soldiers. Soldiers go there to protect Fulani and the cattle... A soldier was fined to pay the bullet money, and he was punished when he fired a shot at a Fulani".

Another elder, Opayin Kwadwo Oduro remarked that:

"Allegedly, the chief of Aberewapong owns cattle. For the nomads to have people who will help their cause, the cattle owners influence DCE elections in the area. These cattle owners are very rich. The people who live in town give hints to the Fulani's outside town. This makes the work of the soldiers difficult... This is because there is a disconnect between the soldiers and the people. The people are not part of the security team though they know the hide-out of the nomads.... The nomads have a hide-out where helicopters of the OPERATION COW LEG cannot even see them".

The secretary to the Agogo Youth Association was of the opinion that:

The police are given money (bribe) which is even more than their salary. They are also given cattle to rear... At times the cattle owners even let their herdsmen rear the cattle for them. The affected areas are far from the main Agogo Township.

One farmer stated that:

"Chiefs are giving land to the cattle owners privately and some are fully engaged in the cattle business. Cattle rearing is a good business. Also, the police don't support us. They come to us on our farms to ask us some irrelevant questions. Oftentimes, you must identify the cattle when you report a nomad to the Police. This is impossible because they are not in a kraal. How can you get witnesses too? You cannot also know where the Fulani stays; you cannot locate them at one particular place. Nomads believe that cattle should walk free as human beings. This is because they are born free, and so they should walk free. A Fulani person has the authority to command a farmer to leave a place where their cattle feed or drink".

It is evident from the preceding responses that a number of factors impeded the various conflict management methods employed to control the conflict between the farmers and nomads at Agogo. The major hindrances to the conflict included, but were not limited to the use of deadly weapons by the nomads and ineffective policing, interference from high profile personalities, leading to the disregard for the rule of law, and personal and political interests. Also, the 
politicization of the conflict and the policy of the ranching system contributed significantly to the unresolved nature of the farmer-herder conflict in the Agogo area. As the researchers have already pointed out, interference or influence by some high profile personalities (Big men) in and outside the Agogo area participated in a number of issues that actually militated against the management of the conflict in the Agogo area. Thus, the influence or interference was the reason the nomads were able to disregard the orders of the court, one of the steps (arbitration) by the farmers to resolve the matter. Moreover, politicization, personal interest, and bribery and corruption made it a daunting task in managing the conflict. Guasset (2009) has equally identified, from his consideration of farmer-herder conflicts in the Grassfields of Cameroon that ultimate causes have contributed to the perpetuation of the conflict in the area. Like the multiplicity of factors emanating from interference, as I have identified in this study, Gausset et al. (2009) define ultimate causes to include: socio-political dimensions of resource access, management and ownership rights, power play in the management and ownership of resources between herders and farmers as well as the question of autochthone rights versus 'late-comer' rights in the use and ownership of resources.

As evident from the foregoing responses, personal and political interests accounted for the influence or interference of the various conflict management methods employed to control the conflict in the area. It is probable that this issue gave Fulani the impetus to refuse to leave the area as ordered by the court. It emerged from the results that political leaders lacked the political will to flush out the Fulani's from Agogo and that political leaders used the conflict as political propaganda to exploit political capital and galvanize the support of the electorates in the affected constituencies. This revelation is similarly shared by the Fulani, when during an interview; their spokesperson asserted that "all these people you hear on the radio or see on television claiming to help solve the conflict are all well-known party activists in the area." Clearly, as captured in the words of the farmers and the nomads, the farmer-herder seems to have taken a political twist, thereby making the conflict very difficult to manage.

Similarly, there was laxity on the part of traditional and religious leaders to aid in flushing out the nomads because of some self-seeking interest, as it became clear from the interview that some of the chiefs in the area own some of the cattle; and therefore, would possibly not be interested in the exit of the nomads, which has been the limiting factor to the conflict management process. It was again revealed from the study that the people have a strong perception that the conflict remains insoluble for some seemingly invisible group of individuals who can influence the corridors of power both nationally and regionally through to the district level to benefit from the rearing of the cattle. Those individuals either themselves or their agents constantly see to it that the cattle rearing business goes on, and so wish the nomads continue to stay in Agogo. The findings of this study are also consistent with those by Ibrahim (2014) in his work in Agogo who reported that politicians politicized the conflict and employed political propaganda to exploit political capital and to gain support from the electorate in the affected constituencies. It has even led to electorates voting for who can solve the conflict from local elections through to presidential elections. Some people are therefore using this conflict to also gain political popularity in the area. The people have high hopes for this government as they see the government as the saviour in taking radical measures to eradicate this canker.

Again, the position of the traditional authorities seems to be arrogated as the people do not believe in the traditional authorities' efforts to curb the menace. This made it difficult to effectively co-operate and co-ordinate to nip in the bud the perennial conflicts as observed by (Ibrahim, 2014). This finding also vindicates Ibrahim's (2014) assertion that the conflict was beset with political rivalry in both mainline and traditional politics that make it difficult to deal with the situation decisively. This development has led to a strained relationship between the traditional authorities and their subjects.

\subsection{Bribery and corruption}

Quite apart from the fact that some high-profile personalities interfered or influenced the conflict management methods adopted to control the farmer-herder conflict in the Agogo area, leading to the unsuccessfulness of the various conflict management methods for their political and personal gains, the issue of bribery and corruption also played a crucial part in the influence or interference matter. Thus, it was revealed that the police who are supposed to enforce law and order by ensuring that the orders of the court are strictly followed were rather taking bribes from the Fulani, thereby strengthening the activities of the herdsmen. This can be found in the response given by one of the participants: the police are given money (bribe) which is even more than their salary. They are also given cattle to rear... At times the cattle owners even let their herdsmen rear the cattle for them. Well, in this regard, I should state that this is just an 
allegation from a participant since, during my interview with him, there was no proof to this very allegation; however, there seem to be some facts in this revelation since the Fulanis have equally revealed that the police charge them an exorbitant amount of money for their (the nomads) activities in the area.

The researchers opine here that, given the operations of the police in the country, there was little that the police could do in protecting the activities of the nomads if not for the influence and interference from some influential people in and outside the area. That is, at the initial stage when the matter was settled at the law court for the nomads to exit the area, it became final and binding on the police force to ensure that the nomads followed the orders of the law court by leaving the area, but since there seem to be some authorities whose powers go beyond the Agogo area and do not want the nomads to leave the area, the nomads continued to live in the area, while their cattle continued to destroy the crops of the farmers. That notwithstanding, the police could have used their jurisdictional mandate in protecting the lives of the indigenes, but due to some reason, they turned their back on the indigenes by allowing the Fulanis to persistently countenance the destruction of the farmers' crops; and afflict them with pain. And as the indigenes or the farmers realized that they seemed to have no support from the state, particularly the police, they decided to put their destinies in their own hands by protecting their properties and their lives; and this really explains the reason why the farmer-herder conflict has continued till now.

However, it became clear from the interview that though the ranching system could have been an antidote to resolving the farmer-herder conflict in the Agogo area, the cattle owners considered the ranching system expensive rather than the crops their animals destroyed. Of course, much money would go into the rearing of the cattle if they had resorted to the ranching system, but since they do not want to do it because it is expensive, they boycotted that idea at the expense of the ordinary farmer as noted from the responses of the interviewees.

Since the ranching system was not followed and also once the nomads did not follow the orders of the law court by leaving the place, there was no way the farmer-herder conflict could have been managed in that obviously, there would be no place for the cattle to graze except in the farms of the indigenes. Also, the indigenes could not afford to stop farming since a majority of them depend on farming for their survival.

\section{Conclusions}

The study revealed that the conflict between the farmers and the nomads in the Agogo could only be dealt with if there are no political powers backing Fulani herdsmen in the enclave of Agogo. This is because the migration of the Fulani herdsmen is surrounded by political, economic, and social factors, as there are middlemen, politicians, chiefs, security officers with a vested interest in the cattle business in Agogo. These do not only attract the Fulani herdsmen, but also make their stay in Agogo more comfortable, and this clearly explains why the various conflict management methods in the Agogo area have all failed. The study also concluded that the Fulanis have been able to defy the orders of the court by not withdrawing from the Agogo area, this clearly shows that there is nothing to be done to curb the atrocities they are causing in Agogo and its environs. The farmers and nomads' conflict in Agogo rages on because the conflict management methods that have so far been employed have proven ineffective.

\section{Recommendations}

It is recommended that the recurring violent attacks need to be addressed from a local-level perspective by the local government and opinion leaders (bottom-up peace approach) rather than the top-down approach from the national perspective through Operation Cow Leg (OCL). Measures such as the deployment of state security through the use of OCL by the National Security and the formation of national-based committees to investigate and resolve violent attacks have apparently failed to curb the violence. Instead, decentralizing conflict management and resolution at the local level as well as integrating local administrations, farmer associations, cattle owners, nomads, local groups and traditional institutions into conflict resolution will help. This is because people at the local level know the issues of common cooperation and cross-cutting ties between them and the pastoralists which can be enhanced and encouraged. Therefore, it is important to emphasise these cross-cutting ties; everyday peace-building mechanisms and co-existence among them with the aid of local-based organizations/commissions/institutions that are key in the management of the farmers and 
nomads' conflict.

It is also recommended that the Government of Ghana and traditional authorities in Agogo State should be firm and fair in the management and implementation of court decisions with regard to the farmer-nomad conflict of Agogo. The politicisation of farmer and nomad conflicts, in particular, is thwarting efforts at forging cooperation and resolution of the conflict. This politicisation by local actors, government officials, local politicians, cattle owners and community members has deepened the conflict. De-politicising of the farmer-nomad conflict would require the involvement of local institutions, local CSOs (NGOs, CBOs and FBOs) and actors in conflict resolution and peace building since the trust of the local and national government in resolving the conflict are low. These local institutions and actors can serve as neutral brokers in negotiating peaceful co-existence. It is recommended again that, traditional authorities in Agogo should collaborate with the Ministry of Education to carry out intensive public education to educate the citizenry about the nature of the conflict in their enclave.

\section{References}

Adzahlie-Mensah, V., Golo, H. K., \& Gyamfuaa-Abrefa, M. (2016). Approaches to conflict prevention: some societal issues to consider. American Journal of Business and Society, 1(4), 176-182. http://files.aiscience.org/journal/ article/html/70590009.html

Albert, O. I. (1999). Ife-Modakeke crisis. In Otite, O., Albert, I. O. (Eds.), Community conflicts in Nigeria: Management, resolution and transformation (pp. 142-183). Ibadan, Nigeria: Spectrum Books. https://scholar.google.com/ scholar_lookup?hl=zh-CN\&publication_year=1999\&pages=142-183\&author=I.+O.+Albert\&title=Community + co nflicts $+\overline{\text { in}}+$ Nigeria $\% 3 \mathrm{~A}+$ Management $\% 2 \mathrm{C}+$ resolution+and+transformation

Berry, S. S. (2002). Debating the land question in Africa. Comparative Studies in Society and History, 44(4), 638-668. https://doi.org/10.1017/S0010417502000312

Boone, C., \& Duku, D. K. (2012). Ethnic land rights in Western Ghana: Landlord-stranger relations in the democratic era. Development and Change, 43(3), 671-693. https://doi.org/10.1111/j.1467-7660.2012.01778.x

Bukari, K. N., \& Schareika, N. (2015). Stereotypes, prejudices and exclusion of Fulani pas-toralists in Ghana. Pastoralism: Research, Policy and Practice, 5(20), 1-12.

Burton, W. J. (1990). Conflict: Human needs theory. New York: St. Martin's Press. https://link.springer.com/ book/10.1007/978-1-349-21000-8

Creswell, J. W. (2013). Qualitative inquiry \& research design: Choosing among five approaches (3rd ed.). Thousand Oaks, CA: SAGE.

Colin, J. P., \& Ayouz, M. (2006). The development of a land market? Land Economics, 82(3), 404-423. https://doi. org/10.3368/le.82.3.404

Daniel, A. (2003). Farmer-herder conflict over natural resources in North-East Ethiopia: The case of Quowet Wereda in North Shewa Zone of the Amhara National State. Masters thesis, Addis Ababa University. http://thesisbank.jhia. ac.ke/4262/

Diehl, P. F. (1992). Territorial changes and international conflict. International Interactions, 2(5), 91-118.

Dosu, A. (2011, December). Fulani-farmer conflict and climate change in Ghana: Migrant Fulani herdsmen clashing with Ghanaian farmers in struggles for diminishing land and water resources. http://mandalaprojects.com/ice/icecases/fulani.htm

Frederick, A. A., Isaac, L., Genesis, T. Y., Joseph, T., \& David, O. Y. (2014). Management of natural resources in a conflicting environment in Ghana: unmasking a messy policy problem. Journal of Environmental Planning and Management, 57(11), 1724-1745. https://doi.org/10.1080/09640568.2013.834247

Gelpi, C. (2017). Democracies in conflict: The role of public opinion, political parties, and the press in shaping security policy. Journal of Conflict Resolution, SP9, 1925-1949. https://doi.org/10.1177/0022002717721386

Gochman, C. S. (1993). The evolution of disputes. International Interactions Empirical and Theoretical Research in International Relations Journal, 19(1-2), 49-76. https://doi.org/10.1080/03050629308434819

Graphic Online. (2016, April 1). Promote conflict resolution and peacebuilding. https://www.graphic.com.gh/news/general-news/promote-conflict-resolution-and-peacebuilding.html

Guasset, M., Swarner, M. J., Mponwane, L., Keletile, K., \& McNutt, J. W. (2009). Human-wildlife conflict in northern Botswana: livestock predation by endangered African wild dog lycaon pictus and other carnivores. Fauna \& Flora International, Oryx, 43(1), 67-72. https://doi.org/10.1017/S0030605308990475 
Hudson, B., Hunter, D., \& Peckham, S. (2019). Policy failure and the policy-implementation gap: can policy support programs help. Policy Design and Practice, 2(1), 1-14.

Ibrahim, B. (2014). Farmer-herder conflicts: A case study of Fulani herdsmen and farmers in The Agogo traditional Area of the Ashanti Region. Published M. A thesis. University of Ghana, Legon. http://ugspace.ug.edu.gh/bitstream/ handle/123456789/7253/Ibrahim\%20Baidoo_\%20\%20Farmer-Herder\%20Conflicts\%20A\%20Case\%20Study\%20 Of $\% 20$ Fulani $\% 20$ Herdsmen $\% 20$ And $\% 20$ Farmers\%20in\%20the\%20Agogo\%20Traditional\%20Area\%20of\%20 the\%20Ashanti\%20Region_2014.pdf;jsessionid=AD0A8E3EE0AADBB6964A54E77D87719F?sequence=1

Jumba, A. H. (2011). Farmer-herder conflict: Exploring the causes and management approaches in the Lake Chad region Nigeria. PhD. Thesis. Universiti Utara Malaysia. http://etd.uum.edu.my/3399/2/1.HAMMAN_JUMBA_ AHMADU.pdf

Maiangwa, J., \& Ahmadu, H. J. (2007). Reflections on and insights into the Nigeria's political instability since independence: Alternative proposal for consideration. Maiduguri Journal of Arts and Social Science, 5(2), 27-36.

Miller, C. A. (2005). A glossary of terms and concepts in peace and conflict studies. Geneva: University for Peace.

Milligan, S., \& Binns, T. (2007). Crisis in policy, policy in crisis: understanding environmental discourse and resourceuse conflict in northern Nigeria. The Geographical Journal, 173(2), 143-156. https://doi.org/10.1111/j.14754959.2007.00231.x

Miluwi, J. O. (2015). International conflict resolution and preventions: issues and opportunity for peace in the 21st century. International Journal of Political Science and Development, 3(1), 15-29.

Obeng, M. (2015). Farmer-herder conflicts in sub-Saharan Africa. International Journal of Peace Research, 31(3), 333349.

Olaniyan, A., Francis, M., \& Okeke-Uzodike, U. (2015). The cattle are "Ghanaians" but the herders are strangers: Farmer-herder conflicts, expulsion policy, and pastoralist question in Agogo, Ghana. African Studies Quarterly, 15(2), 53-67. https://asq.africa.ufl.edu/olaniyan-francis-okekeuzodike_march15/

Opoku, P. (2014). Exploring the causes and management of pastoralists-farmer conflicts in Ghana. Journal of Energy and Natural Resource Management, 1(3), 170-175. https://doi.org/10.26796/jenrm.v1i3.61

Schelling, T. C. (1960). The strategy of conflict. Cambridge, MA: Harvard University Press.

Seidu, Y. (2012). Human resource management and organizational performance: evidence from the retail banking sector. Aston: Aston University. http://publications.aston.ac.uk/id/eprint/16500/

Snyder, G. H., \& Diesing, P. (2015). Conflict among nations: bargaining, decision making, and system structure in international crises. Princeton: Princeton University Press.

Soeters, S., Weesie, R., \& Zoomers, A. (2017). Agricultural investments and farmer-fulani pastoralist conflict in West African Drylands: A northern Ghanaian case study. Sustainability, 9(11), 2063. https://doi.org/10.3390/su9112063

Stoll, D. (1993). Between two armies in the Ixil towns of Guatemala. Journal of the Royal Anthropological Institute, 6(1), 217-230. https://doi.org/10.1111/1467-9655.t01-1-00009

Toku, E. (2014). Conflict management practices in selected basic schools in the ashanti region. Master of Business Administration Thesis Published by Kwame Nkrumah University of Science and Technology. http://ir.knust.edu. gh/bitstream/123456789/7633/1/FINAL\%20FINAL\%20PROJECT\%20MBA.pdf

Tonah, S. (2002). Fulani pastoralists, indigenous farmers and the contest for land in Northern Ghana. Africa Spectrum, 37(1), 43-59. https://www.jstor.org/stable/40174917

Waltz, K. (1979). The theory of international politics. Reading, MA: Allusion Wisely.

Wehrman, B. (2008). Land conflicts: a practical guide to dealing with the disputes. Eschborn GTZ.

Young, C., Habarth, J., Bongar, B., \& Packman, W. (2018). Disorder in the court: cluster B personality disorders in United States case law. Psychiatry, Psychology and Law, 25(5), 706-723. https://doi.org/10.1080/13218719.2018.1 474816 